\title{
TRIAL OF A VASODILATOR ON TROPHIC ULCERS
}

\author{
By E. P. Vaidyanathan, M.B.B.S. \\ Medical Officer, (Belgian) Leprosy Centre, \\ Polambakkam, South India
}

\section{Introduction}

We are faced with the problem of treating plantar trophic ulcers in leprosy. These cases occupy a larger number of hospital beds than cases such as lepra reaction or any other concurrent disease.

Treatments of the ulcers are many according to the extent of the lesion, discharge from the ulcer, and the involvement of the underlying bone. Ulcers without discharge or involvement of bone can successfully be treated with full cast plaster of paris bandage to the leg applied at the roadside clinic itself, but patients having chronic recurrent ulcers with marked oedema of the foot and serious discharge cannot be treated with plaster of paris immobilisation and they need prolonged hospitalisation and special treatment.

It is known that sclerosis and fibrosis lead to extra-vascular compression and narrowing of the blood vessels in the region of the trophic ulcers. Dharmendra, Sen, \& ChatterJI² hold that diminution in the blood supply is a fundamental cause of persistent ulceration.

LAURET and KERBASTARD ${ }^{3}$ treated 17 perforating ulcers with trichloracetic acid and salicylic acid externally and intravenous injection of Dycholium (dehydrocholate of sodium). They attribute the good results to the antiseptic and epithelial softening actions of the acid and the vasodilatation brought about by the bile salts.

PATERSON $^{4}$ from a series of angiographs concluded that there is dilatation of the arteriovenous shunts and sometimes there is defective filling of the digital arteries due to short circuit of blood.

Hence it was felt that any drug which would increase the blood flow to the affected part might promote quicker healing of these ulcers. This led me to the trial of nicotinic acid, a vasodilator drug, in the treatment of plantar trophic ulcers which forms the subject of this paper.

\section{Pharmacology}

Pyridine B-carboxylic acid is nicotinic acid having the following formula: 


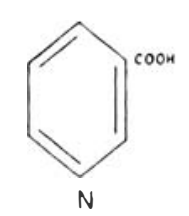

Nicotinic acid is capable of producing marked vasodilation particularly of the capillary bed.

For the purpose of this trial Pelonin of the Glaxo laboratories was used.

\section{Selection of material for study}

Each case was selected on the following criterion:

Secondary infection and bony involvement were absent and the ulcers had serous discharge.

The patients were of all types of leprosy and all of them were on sulphone treatment.

\section{The method}

The patient was seated on a high stool with the leg hanging down and a pneumatic cuff of the sphygmomanometer was applied over the thigh at a pressure of $110 \mathrm{mg}$. of mercury. $100 \mathrm{mg}$. of nicotinic acid, i.e., two ampoules of $50 \mathrm{mg}$. Pelonin, each ampoule containing $2 \mathrm{ml}$. was injected into the long saphenous vein in the leg which had the ulcer, keeping the pneumatic tourniquet on for five minutes to prevent the drug from flowing proximally. The treatment was given only thrice weekly and the ulcers were dressed with dry sterile gauze on alternate days. The patients were not strictly confined to bed. They were not aware that a trial was being made.

As a control, a few cases were given $4 \mathrm{ml}$. of distilled water intravenously, instead of Pelonin.

The blood pressures of the individuals were recorded before and after the administration of the drug.

\section{Results}

In the nicotinic acid group, out of 18 ulcers, 4 healed within 10 days, 8 healed within 22 days, 3 healed in 30 days and the rest within 60 days. Whereas in the control group with distilled water, out of 9 ulcers, only 2 healed within 30 days and the rest did not show any sign of improvement even after 30 days.

Nicotinic acid group-See table I.

Control group-See table II. 
TABLE I

\begin{tabular}{|c|c|c|c|c|c|c|c|c|c|}
\hline $\begin{array}{l}\text { S. } \\
\text { No. }\end{array}$ & Name & $\begin{array}{l}\text { Sex } \\
\text { and } \\
\text { Age }\end{array}$ & Type & Site of ulcer & $\begin{array}{c}\text { Size of ulcer } \\
\text { (Length } \times \text { Breadth } \\
\times \text { Depth })\end{array}$ & $\begin{array}{c}\text { Duration } \\
\text { of } \\
\text { Ulcer }\end{array}$ & $\begin{array}{l}\text { Duration } \\
\text { of } \\
\text { Treatment }\end{array}$ & $\begin{array}{l}\text { No.of } \\
\text { Injec- } \\
\text { tions } \\
\text { given }\end{array}$ & Remark \\
\hline \multirow[t]{2}{*}{1} & \multirow[t]{2}{*}{ S. } & \multirow[t]{2}{*}{ Male/30 } & \multirow[t]{2}{*}{ Polyneuritic } & Lateral edge of foot & & & & & \\
\hline & & & & 4th and 5th metatarsals & $4 \mathrm{~cm} \times 3 \mathrm{~cm} \times 1 \mathrm{~cm}$ & 3 years & 60 days & 24 & Healed \\
\hline 2 & C. & Male 60 & Polyneuritic & Head of 2 nd metatarsal & $2 \mathrm{~cm} \times 2 \mathrm{~cm} \times 5 \mathrm{~mm}$ & l year & 11 days & 5 & .. \\
\hline 3 & v. & Female $/ 37$ & Polyneuritic & $\begin{array}{l}\text { Heads } 2 \text { nd, } 3 \text { rd and } 4 \text { th } \\
\text { metatarsals }\end{array}$ & $3 \mathrm{~cm} \times 2 \mathrm{~cm} \times 1 \mathrm{~cm}$ & 9 months & 41 days & 15 & , \\
\hline \multirow[t]{2}{*}{4} & \multirow[t]{2}{*}{ L. } & \multirow[t]{2}{*}{ Male $/ 25$} & \multirow[t]{2}{*}{ Tuberculoid } & Head of 2 nd metatarsal & $4 \mathrm{~mm} \times 3 \mathrm{~mm} \times 2 \mathrm{~mm}$ & 7 months & 30 days & 12 & .. \\
\hline & & & & Head of 5th metatarsal & $1 \mathrm{~cm} \times 1 \mathrm{~cm} \times 1 \mathrm{~mm}$ & 7 months & 20 days & 9 & , \\
\hline 5 & A. & Male/29 & Polyneuritic & Head of 1 st metatarsal (New) & $1.5 \mathrm{~cm} \times 1.5 \mathrm{~cm} \times 9 \mathrm{~mm}$ & 6 months & 25 days & 10 & .. \\
\hline \multirow[t]{2}{*}{6} & \multirow[t]{2}{*}{ A. } & \multirow[t]{2}{*}{ Male $/ 35$} & \multirow[t]{2}{*}{ Borderline } & Head of 1st metatarsal & $2.5 \mathrm{~cm} \times 2.5 \mathrm{~cm} \times 2 \mathrm{~cm}$ & 5 months & 22 days & 9 & ", \\
\hline & & & & Heads 3 rd, 4 th metatarsals & $2.5 \mathrm{~cm} \times 2.5 \mathrm{~cm} \times 1 \mathrm{~cm}$ & 4 months & 14 days & 6 & .. \\
\hline 7 & S. & Male/16 & Borderline & Heads of $3 \mathrm{rd}, 4$ th metatarsals & $1 \mathrm{~cm} \times 1 \mathrm{~cm} \times 1 \mathrm{~cm}$ & 3 months & 23 days & 9 & ", \\
\hline 8 & $\mathrm{~K}$. & Male/15 & Indeterminate. & Head of 2 nd metatarsal & $2 \mathrm{~cm} \times 1.5 \mathrm{~cm} \times 1 \mathrm{~cm}$ & 2 months & 16 days & 7 & , \\
\hline 9 & D. & Male $/ 43$ & Lepromatous & Head of 1st metatarsal & $1 \mathrm{~mm} \times 1 \mathrm{~mm} \times 1 \mathrm{~cm}$ & 2 months & 10 days & 4 & $"$ \\
\hline \multirow[t]{2}{*}{10} & \multirow[t]{2}{*}{ P. } & \multirow[t]{2}{*}{ Female $/ 28$} & \multirow[t]{2}{*}{ Tuberculoid } & \multirow{2}{*}{$\begin{array}{l}\text { Shaft of 5th metatarsal } \\
\text { and Heel }\end{array}$} & $2 \mathrm{~cm} \times 2 \mathrm{~cm} \times 1 \mathrm{~mm}$ & 2 months & 7 days & 3 & , \\
\hline & & & & & $2 \mathrm{~cm} \times 2 \mathrm{~cm} \times 2 \mathrm{~mm}$ & 30 days & 10 days & 4 & , \\
\hline \multirow[t]{2}{*}{11} & \multirow[t]{2}{*}{$\mathrm{K}$. } & \multirow[t]{2}{*}{ Male/35 } & \multirow[t]{2}{*}{ Lepromatous } & \multirow{2}{*}{$\begin{array}{l}\text { Base of terminals phalanx } \\
\text { of great toe }\end{array}$} & & & & & \\
\hline & & & & & $1 \mathrm{~cm} \times 1 \mathrm{~cm} \times 1 \mathrm{~mm}$ & $2 \mathrm{~mol}$ & 33 days & 13 & " \\
\hline 12 & D. & Male/32 & Tuberculoid & Head of 2nd metatarsal (New) & $1.3 \mathrm{~cm} \times 1 \mathrm{~cm} \times 1 \mathrm{~cm}$ & 2 months & 5 days & 2 & \\
\hline 13 & C. & Male/39 & Lepromatous & Heads of 4 th, 5 th metatarsals & $3 \mathrm{~cm} \times 2 \mathrm{~cm} \times 1.5 \mathrm{~cm}$ & 2 months & 45 days & 16 & $"$ \\
\hline \multirow[t]{2}{*}{14} & \multirow[t]{2}{*}{ A. } & \multirow[t]{2}{*}{ Male/31 } & \multirow[t]{2}{*}{ Tuberculoid } & \multirow{2}{*}{$\begin{array}{l}\text { Base of terminal phalanx } \\
\text { of great toe }\end{array}$} & & & & & 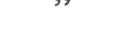 \\
\hline & & & & & $2.6 \mathrm{~cm} \times 1.9 \mathrm{~cm} \times 1 \mathrm{~cm}$ & 45 days & 19 days & 8 & ", \\
\hline \multirow[t]{2}{*}{15} & \multirow[t]{2}{*}{ K. } & Male/36 & Tuberculoid & Base of terminal phalanx & & & & & \\
\hline & & & & of great toe & $1.5 \mathrm{~cm} \times 1 \mathrm{~mm} \times 2 \mathrm{~mm}$ & 45 days & 14 days & 6 & , \\
\hline
\end{tabular}




\section{Side effects}

Soon after releasing the cuff, in the nicotinic acid group, all of them had flushing and some had gastric discomfort, which lasted for a few minutes.

\section{Discussion and conclusions}

The results with nicotinic acid were encouraging. Fresh crops of healthy granulation tissue were seen sprouting up in the ulcers on the third day. As seen in table I, ulcers of short duration and the first ulcers healed rapidly. 11 patients who were admitted for skin diseases who had also ulcers without bony involvement were given Pelonin $100 \mathrm{mg}$. daily orally as part of their treatment for the skin disease. It was noted that these ulcers took on an average about two months to heal in spite of local dressings. CAVER ${ }^{1}$ tried Roniacol, a vasodilator orally in 3 plantar ulcers and found no significant improvement. Ulcers treated with distilled water also took a long time to heal and healthy granulation tissue as seen in ulcers treated with nicotinic acid was not present.

These findings lead me to conclude that:

1. Vasodilatation plays a greater part than previously thought in healing of the ulcers.

2. Nicotinic acid is a useful drug for the treatment of plantar ulcers.

3. Nicotinic acid given intravenously has a better effect than administered orally.

\section{Summary}

1. A vasodilator, nicotinic acid (Pelonin) was tried intravenously for the treatment of plantar trophic ulcers without local dressings.

2. 15 persons with 18 ulcers were put on nicotinic acid.

3. 5 persons with 9 ulcers were kept as control with distilled water injections.

4. 11 cases were treated with nicotinic acid orally.

5. Healing of the ulcers were quicker in the nicotinic acid group (intravenous), and the first ulcers more rapidly.

\section{Acknowledgment}

Grateful thanks are due to Dr. (Miss) C. Vellut, Medical Officer in charge, for supplying the drug for trial and permitting me to publish this article. Thanks are due to Dr. K. Ramanujam of Madras for his useful suggestions, criticisms and comments.

I am also thankful to the staff of this centre who helped me and to the patients without whose co-operation this work would not have been possible. 
TABLE II

(Control Group)

\begin{tabular}{|c|c|c|c|c|c|c|c|c|}
\hline $\begin{array}{c}S . \\
\text { No. }\end{array}$ & Name & $\begin{array}{l}\text { Sex } \\
\text { and } \\
\text { Age }\end{array}$ & Type & Site of ulcer & $\begin{array}{l}\text { Size of ulcer } \\
(\text { Length } \times \text { Breadth } \\
\times \text { Depth })\end{array}$ & $\begin{array}{l}\text { Duration } \\
\text { of } \\
\text { Ulcer }\end{array}$ & $\begin{array}{c}\text { Duration } \\
\text { of } \\
\text { Treatment }\end{array}$ & Remark \\
\hline 1 & $\mathrm{~S}$. & Male/38 & Lepromatous & Head of 1 st metatarsal & $2 \mathrm{~cm} \times 1 \mathrm{~cm} \times 2 \mathrm{~mm}$ & 20 days & 60 days & Not healed \\
\hline 2 & M. & Male $/ 42$ & Lepromatous & $\begin{array}{l}\text { Head of 3rd metatarsal } \\
\text { Head of } 1 \text { st metatarsal } \\
\text { Shaft of 3rd metatarsal }\end{array}$ & $\begin{array}{l}2 \mathrm{~cm} \times 2 \mathrm{~cm} \times 1 \mathrm{~mm} \\
2 \mathrm{~cm} \times 2 \mathrm{~cm} \times 3 \mathrm{~mm} \\
1 \mathrm{~mm} \times 1 \mathrm{~mm} \times 0.2 \mathrm{~cm}\end{array}$ & $\begin{array}{l}6 \text { months } \\
2 \text { months } \\
2 \text { months }\end{array}$ & $\begin{array}{l}45 \text { days } \\
30 \text { days } \\
30 \text { days }\end{array}$ & $\begin{array}{l}", \\
",\end{array}$ \\
\hline 3 & P. & Male $/ 40$ & Tuberculoid & $\begin{array}{l}\text { Head of } 2 \text { nd metatarsal } \\
\text { Heel }\end{array}$ & $\begin{array}{lll}1.5 \mathrm{~cm} \times 1 & \mathrm{~cm} \times 1 & \mathrm{~cm} \\
2.5 \mathrm{~cm} \times 2 & \mathrm{~cm} \times 2 \mathrm{~cm}\end{array}$ & $\begin{array}{l}6 \text { months } \\
6 \text { months }\end{array}$ & $\begin{array}{l}60 \text { days } \\
60 \text { days }\end{array}$ & , \\
\hline 4 & M. & Male $/ 45$ & Tuberculoid & Head of 5th metatarsal (New) & $1 \mathrm{~cm} \times 2 \mathrm{~cm} \times 0.2 \mathrm{~cm}$ & 1 month & 28 days & Healed \\
\hline 5 & G. & Male/39 & Tuberculoid & $\begin{array}{l}\text { Head of } 1 \text { st metatarsal (New) } \\
\text { Head of 5th metatarsal (New) }\end{array}$ & $\begin{array}{l}3 \mathrm{~cm} \times 3 \mathrm{~cm} \times 2 \mathrm{~mm} \\
2 \mathrm{~cm} \times 1.5 \mathrm{~cm} \times 1 \mathrm{~mm}\end{array}$ & $\begin{array}{l}1 \text { month } \\
1 \text { month }\end{array}$ & $\begin{array}{l}30 \text { days } \\
30 \text { days }\end{array}$ & $\begin{array}{l}\text { Not healed } \\
\text { Healed }\end{array}$ \\
\hline
\end{tabular}




\section{References}

1. Caver, C. V., "Treatment of Trophic Ulcers of Leprosy with Roniacol". Int. J. of Lep., 25, (1957), 9-12.

2. Dharmendra, ChatterJi, S. N., and Sen, N. R., "A By-Product of DDS for Treatment of Trophic Ulcers in Leprosy-Leprosy in India" 7, (1955), 180-185.

3. Lauret, L., and Kerbastard, P., "Treatment of Ulcerating Fissures and Perforating Ulcers with a Combination of Trichlor-acetic Acid and Salicylic Acid", Med. Trop. Marseilles (1956), Jan.-Feb. v. 16, No. 1, 83-92.

4. Paterson, D. E., "Radiological Bone Changes and Angiographic Findings in Leprosy", J. Fac. Radiol. (London), 7, (M 55), 35-46. 